\title{
Regional Differences in Income and Involvement in the Use of DFS as Factors of Influence on the Population Financial Literacy
}

\author{
Elena Razumovskaya ${ }^{1,2, *}$ Denis Razumovskiy ${ }^{1,2}$
}

\author{
${ }^{1}$ Department of Finance, Money Circulation and Credit, Ural Federal University named after B.N. Yeltsin, \\ Yekaterinburg, Russia \\ ${ }^{2}$ Department of Finance, Money Circulation and Credit, Ural State University of Economics, Yekaterinburg, Russia \\ *Corresponding author. Email: rasumovskaya.pochta@gmail.com
}

\begin{abstract}
The article attempts to analyze the impact of regional differences in income and activity of using digital financial services (DFS) on the financial literacy of the population. The authors proceeded from the hypothesis that the effect of concentration of financial activity in large federal centers of the Russian Federation on other territories, in particular, the Sverdlovsk region, is approximated. The main research hypothesis is that the regular and active use of digital financial services is more inherent with people living in large settlements and having a relatively higher income; these two factors have a decisive influence on the level of financial literacy. The use of constantly developing digital financial services in everyday life allows people to visualize the dynamics of their financial capabilities, analyze and adjust the structure of financial resources, which increases financial knowledge and strengthens skills.
\end{abstract}

Keywords: financial literacy, household financial resources, digital financial services

\section{INTRODUCTION}

Acute social orientation studies are being updated under conditions of economic instability; therefore, permanent consequences of geopolitical tensions and the 2014 devaluation shock, the overcoming of which is associated with the need to restore the most important financial and economic criteria for the state of the national economy of the Russian Federation, have determined the need to study factors affecting financial behavior of the population. The authors classify the following as the most important financial and economic indicators: gross domestic product (GDP), real income of the population, the pace of industrial production, investment and consumer activity, which determine dynamics of the retail sector (Figure 1).



Figure 1 Quarterly indicative dynamics of key financial and economic indicators of the state of the national economy of the Russian Federation, 2014-19 [4] 
As can be seen from Figure 1, the 3rd quarter of 2015 was the most difficult period - the deepest 'failures' in the dynamics of investment activity fell on this period. Throughout 2015, decline trends are seen in production (due to capital outflow) and in trade (due to inflation). The most significant reductions occurred in real income of the population, investment activity and consumer demand.

The authors' attention to consumer demand is due to its positioning as an identifying parameter of the current state of the national economy. The recovery and even some increase in consumption in 2017 was associated with active consumer lending, as incomes of the population continued to stagnate. The growth of consumer lending can be characterized as unsecured and even risky - the rising cost of goods due to the cost of loans was not offset by the comparable dynamics of disposable income, which formed a public request for redistributive trends in social policy from the state, compensating consumer spending.

\section{ARTICULATION OF ISSUE AND METHODS}

For the purposes of this study, financial literacy is interpreted by the authors as a kind of synergistic combination of financial activity, awareness, knowledge, skills, attitudes and behavior, implemented in making rational financial decisions in order to achieve financial well-being. The latter is a consequence of the influence of macroeconomic, geopolitical, social and financial factors on the living conditions of the population. The conditions themselves, in the same external environment, are distorted by regional differences. Table 1 shows social, financial and economic inequality due to high concentration in the federal centers of the influence of agglomeration and institutional factors.

Table 1. Agglomeration and institutional factors of concentration of financial and economic indicators of the federal centers of the Russian Federation [4]

\begin{tabular}{|l|l|l|l|l|}
\hline Share from the Russian Federation, $\%$ & Moscow & $\begin{array}{l}\text { Moscow and } \\
\text { Moscow region }\end{array}$ & $\begin{array}{l}\text { St. } \\
\text { Petersburg }\end{array}$ & $\begin{array}{c}\text { St. Petersburg and } \\
\text { Leningrad region }\end{array}$ \\
\hline Population & 8.5 & 14 & 3.6 & 5 \\
\hline GRP & 21 & 26 & 5 & 7 \\
\hline Investments & 14,5 & 20 & 4,5 & 7 \\
\hline New housing supply & 5 & 16 & 5 & 9 \\
\hline Retail turnover & 15 & 23 & 4 & 6 \\
\hline Income of population & 17 & 24 & 5 & 6 \\
\hline Bank deposits & 35 & 41 & 8 & 8 \\
\hline Residential loans & 11 & 19 & 6 & 7.5 \\
\hline Budget income & 20 & 25 & 5 & 6 \\
\hline Budget expenditures on national economy & 27 & 32 & 5 & 6 \\
\hline Budget expenditures on improvement & 56 & 62 & 4 & 5 \\
\hline Budget expenditures on social security benefits & 21 & 27 & 4 & 5 \\
\hline
\end{tabular}

The revealed trends in financial redistribution, which concentrate a significantly more prosperous position of the population in federal centers compared with other regions of the country, have the following logic: allocated budget and investment resources to the capital's economy have a higher turnover due to high business activity, reproducing a comparatively higher rate of development of these regions. Such a federal model of redistribution of financial flows forms differences in the level and quality of life of citizens of the capital region and other territories, which is approximated by all other regional trends: for example, residents of large regional cities live better than citizens of regional centers and small settlements - this is a sustainable social financial system, which must be transformed into a socially fair one. Leaving political aspects outside the research vector, the authors see the following fundamental reasons for the existing stratification:

1. Regional differences in the incomes of the population of federal centers and an average indicator for all other regions (Figure 2). As follows from the data in Figure 2, income peaks among residents of federal centers and regions differ significantly: from 50 to 60 thousand rubles to 30 thousand rubles, respectively. Obviously, such a significant gap in the incomes of the country's residents from federal centers makes research in the field of financial behavior, including financial literacy, less informative, since people are in objectively different market conditions, which means they solve different problems. For example, for many residents of the regions, investment financial instruments that capital residents use or seek to use are not interesting and potentially not available. Financial literacy comes from the same category as many people with low incomes simply do not know the terms and their meaning from the sphere of insurance, investment, savings strategy. They do not use it. 2. The demographic imbalance is still observed, and it has not yet been overcome even with the help of measures that are being implemented in Russia, such as an increase in child benefits and expansion of maternity fund to cover the birth of the first child. Thus, according to the Federal State Statistics Service of the Russian Federation (FSSS), the number of births in 2019 was 10.9 per 1000 people, while in 2018 this indicator was at 11.5 per 1000 people - that is, the birth rate decreased by $5.2 \%$ (Figure 3 ). Among the main reasons for such dynamics, experts find financial and economic uncertainty and declining real disposable incomes of the population (Figure 4). 


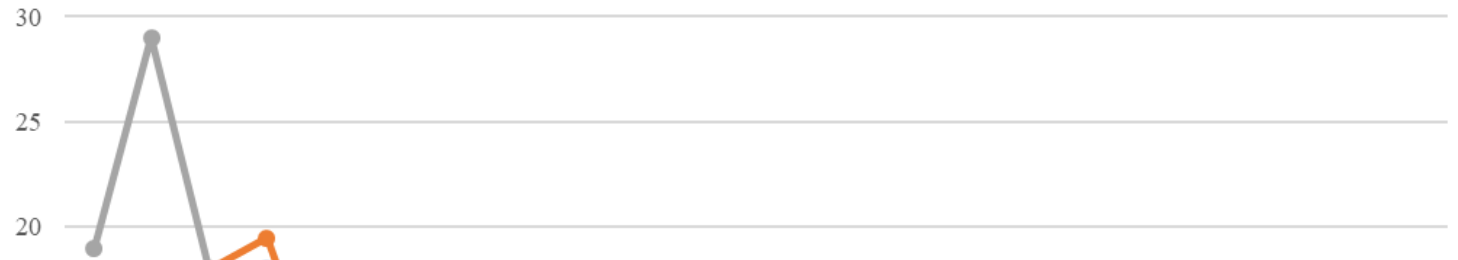

10

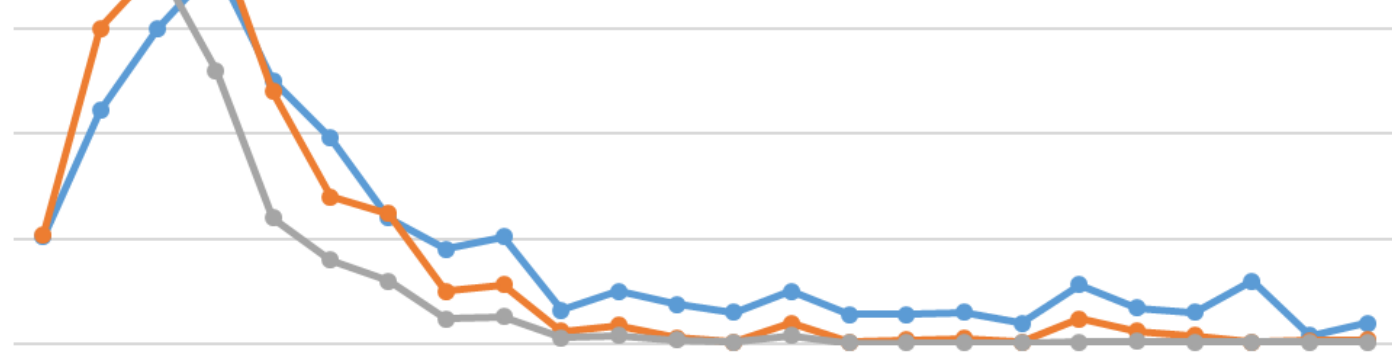

$\begin{array}{llllllllllllllllllllllll}20 & 30 & 40 & 50 & 60 & 70 & 80 & 90 & 100 & 110 & 120 & 130 & 140 & 150 & 160 & 170 & 180 & 190 & 200 & 250 & 300 & 350 & 400 & 450\end{array}$

$\longrightarrow$ Moscow $\longrightarrow$ St. Petersburg $\longrightarrow$ Regions

Figure 2. Differences in income between federal centers and regions of the Russian Federation [3, 4]

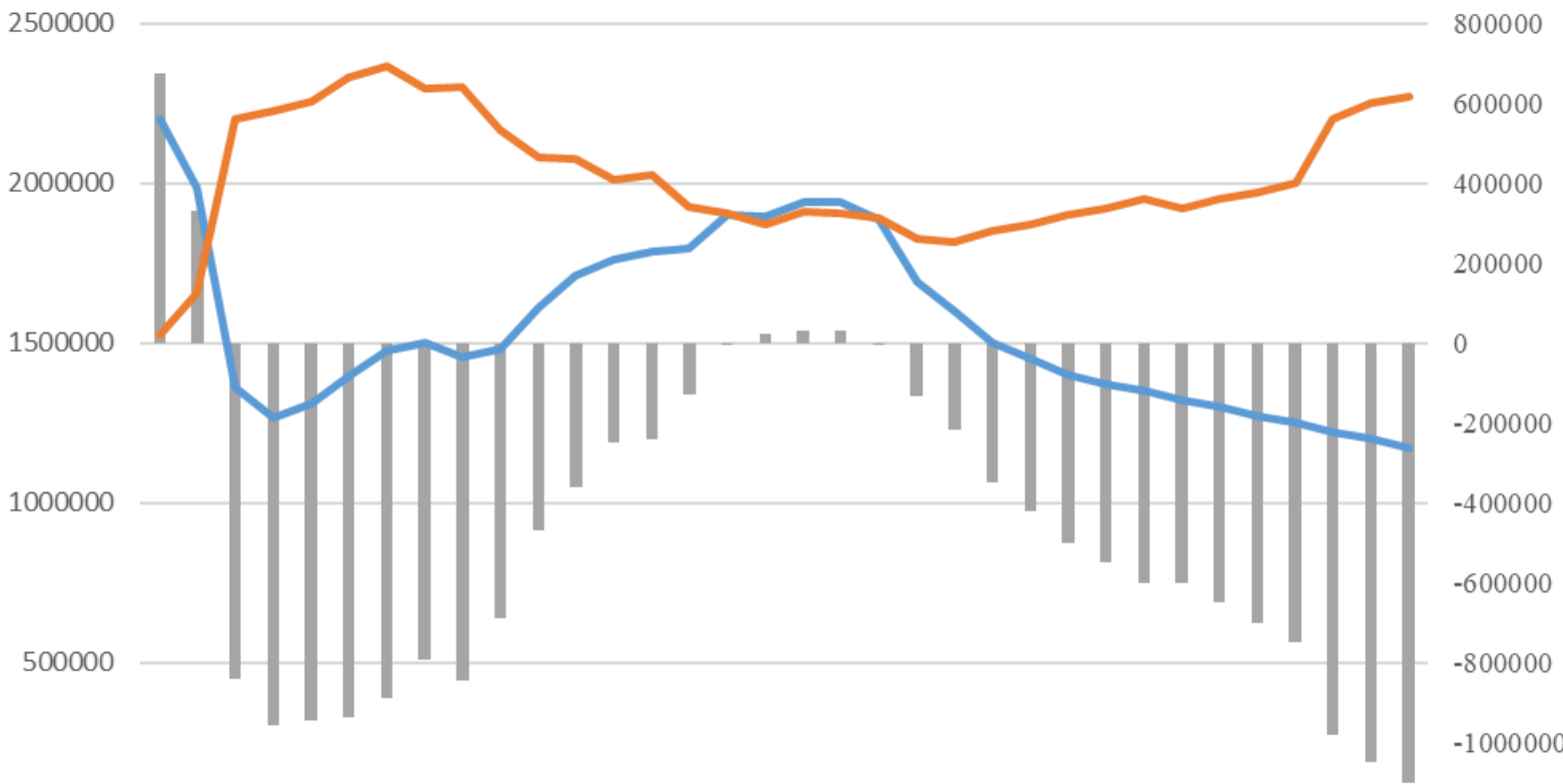

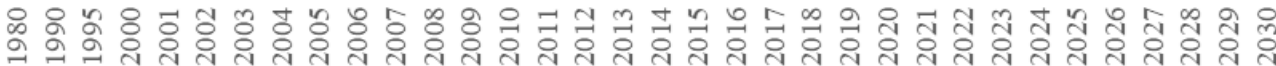

Natural dynamics, people $\quad$ Born, people $\quad$ Dead, people

Figure 3 Demographic dynamics based on forecast [1] 


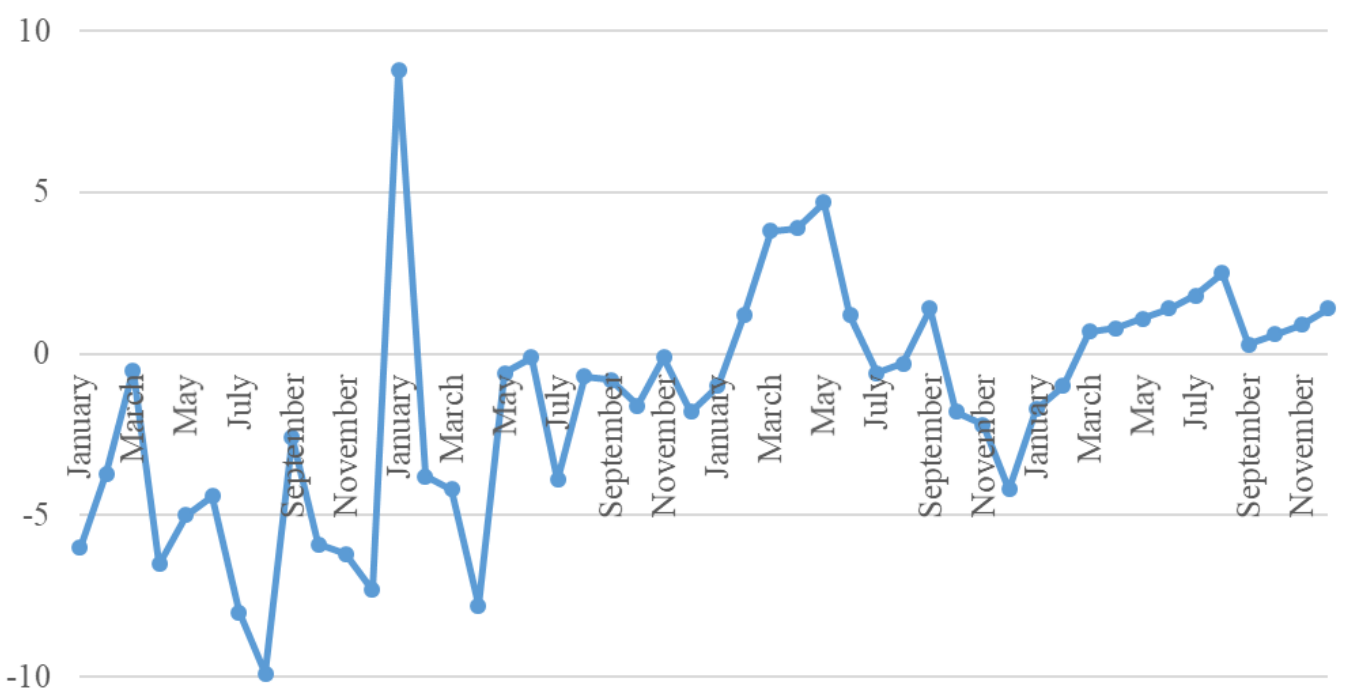

Figure 4. Dynamics of real disposable income of population, \% $[4,5]$

\section{RESEARCH RESULTS}

At the next stage of the study, the authors applied the sociological survey method to assess the level of financial literacy and financial security. This method was chosen as the only method of direct assessment of knowledge. The survey was conducted in public places - shopping centers of the listed cities in September - November 2019 by the continuous survey method - that is, the respondents independently filled out questionnaires with questions related to their identification (gender, age); financial and economic characteristics (assignment to an income group, availability of credit load and cost structure) and directly assessing financial knowledge. The questionnaire was based on the methodology of the Central Bank of the Russian Federation [4] and the National Agency of Financial Research (NAFR) [2]. The survey involved 5,842 people, quantitatively distributed across cities of the Sverdlovsk region (Figure 5):

1) Berezovsky (718 people),

2) Bogdanovich (758 people),

3) Verkhnyaya Pyshma (761 people),

4) Yekaterinburg (847 people),

5) Irbit (710 people),

6) Kamensk Uralsky (745 people),

7) Nizhny Tagil (746 people),

8) Pervouralsk (757 people).

When conducting the study, the authors put forward a hypothesis on the correlation of the financial literacy level and the income level of the respondents, with the latter having differences geographically (Table 2).

The data presented in the table confirm the authors' hypothesis that there is a direct correlation between the size of income and the level of financial literacy of the population.

In addition to assessing the level of financial literacy, the authors analyzed the structure of expenditures of the population of different income groups (Table 3). The authors believe that the rationality of distribution of financial resources by households is also a criterion indicator in assessing financial literacy of the population, since the irrational distribution of income leads to borrowing. As a criterion of optimality in assessing rationality of expenditures, the authors adopted $45 \%$ of expenditures on current consumption in their total value.

As you can see, the most risky from the standpoint of expenditures structure is the revenue group of 21-30 thousand rubles, spending more than $45 \%$ of all their expenses on current consumption. Of course, the authors do not conclude that this category is of the least importance in assessing financial literacy: the reasons why people spend a significant part of their income on current consumption may be temporary difficulties, or, on the contrary, the possibility not to save. However, the perspective of conducting studies to assess the level of financial literacy based on a comprehensively integrative approach can and should include criteria for the structure of expenses, income groups, regions of residence and the activity of using digital financial services (Figure 6).

In addition, measures are needed to popularize the use of digital financial services, which allow people to monitor the status of their financial resources on a daily basis and take into account their financial situation when making financial decisions on managing income. These measures include efforts undertaken by the National Agency of Financial Research (NAFR) and regional centers of financial literacy to conduct educational events: training seminars, 
population, which allow the formation of predictive models of people's financial behavior for various, especially stressful external conditions: price shocks, spikes and declines in the financial parameters of the national economy [13].

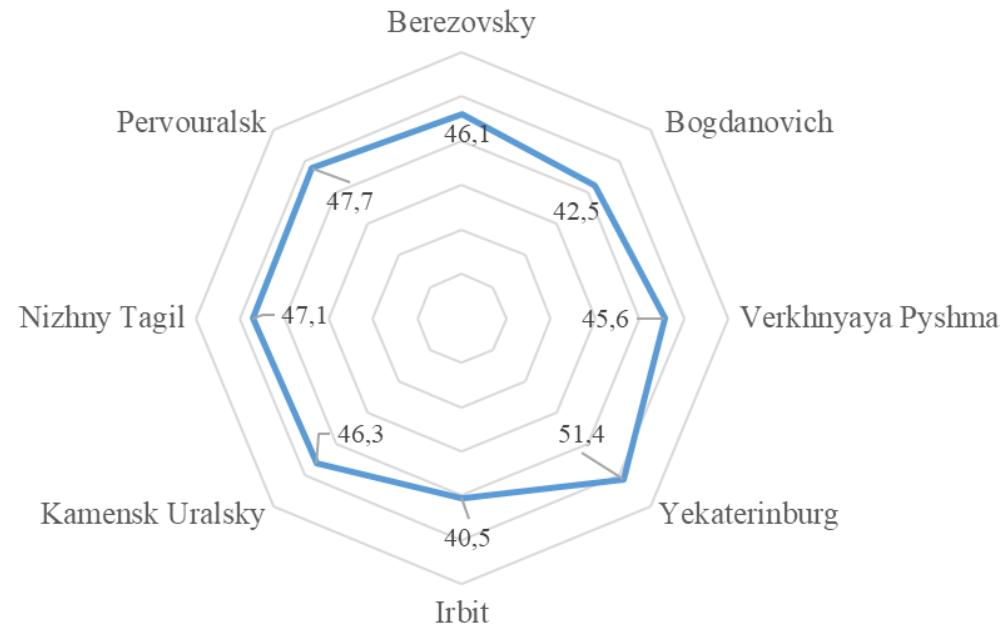

Figure 5. Assessment results of the financial literacy level of the population in the cities of the Sverdlovsk region, $\%$

Table 2. Correlation between income level and financial literacy of the population of Sverdlovsk region

\begin{tabular}{|l|l|l|}
\hline City name & Average wage, rubles & Financial literacy level, \% \\
\hline Yekaterinburg & 39830 & 51.4 \\
\hline Pervouralsk & 36694 & 47.7 \\
\hline Nizhny Tagil & 34140 & 47.1 \\
\hline Kamensk Uralsky & 33671 & 46.3 \\
\hline Berezovsky & 31794 & 46.1 \\
\hline Verkhnyaya Pyshma & 31156 & 45.6 \\
\hline Bogdanovich & 28167 & 42.5 \\
\hline Irbit & 27920 & 40.5 \\
\hline
\end{tabular}

Table 3. Structure of expenditures of the Sverdlovsk region's population by interval income groups, $\%$

\begin{tabular}{|l|l|l|l|l|l|}
\hline $\begin{array}{l}\text { Expenditures structure by } \\
\text { categories, \% / Interval income } \\
\text { groups, in thousands of rubles }\end{array}$ & $12-20$ & $21-30$ & $31-40$ & $41-50$ & $>50$ \\
\hline Current consumption & 49.21 & 45.47 & 44.01 & 42.97 & 40.07 \\
\hline Obligatory payments & 20.68 & 19.62 & 19.25 & 17.75 & 16.98 \\
\hline Debentures & 25.29 & 26.44 & 28.56 & 29.13 & 24.91 \\
\hline Development expenditures & 2.37 & 3.41 & 4.22 & 4.26 & 8.71 \\
\hline Savings & 2.48 & 4.17 & 4.89 & 5.41 & 9.33 \\
\hline Total: & 100 & 100 & 100 & 100 & 100 \\
\hline
\end{tabular}




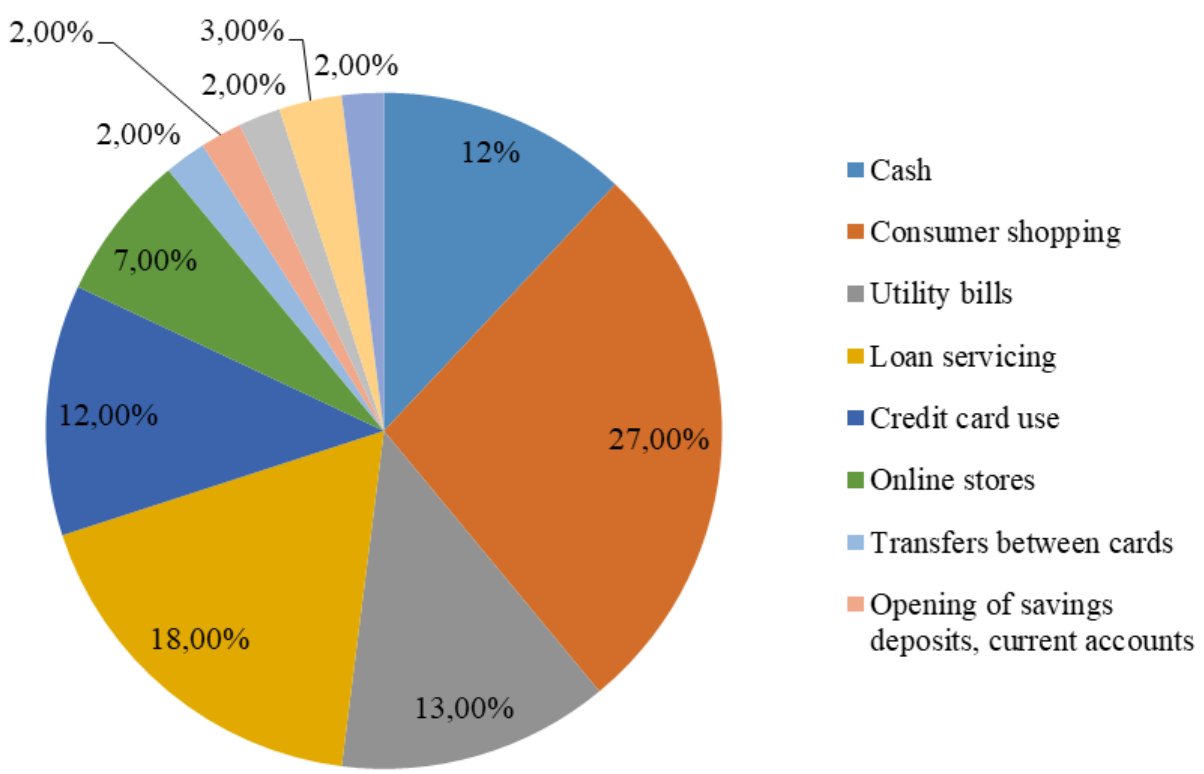

Figure 6. Cash transaction structure of active DFS users

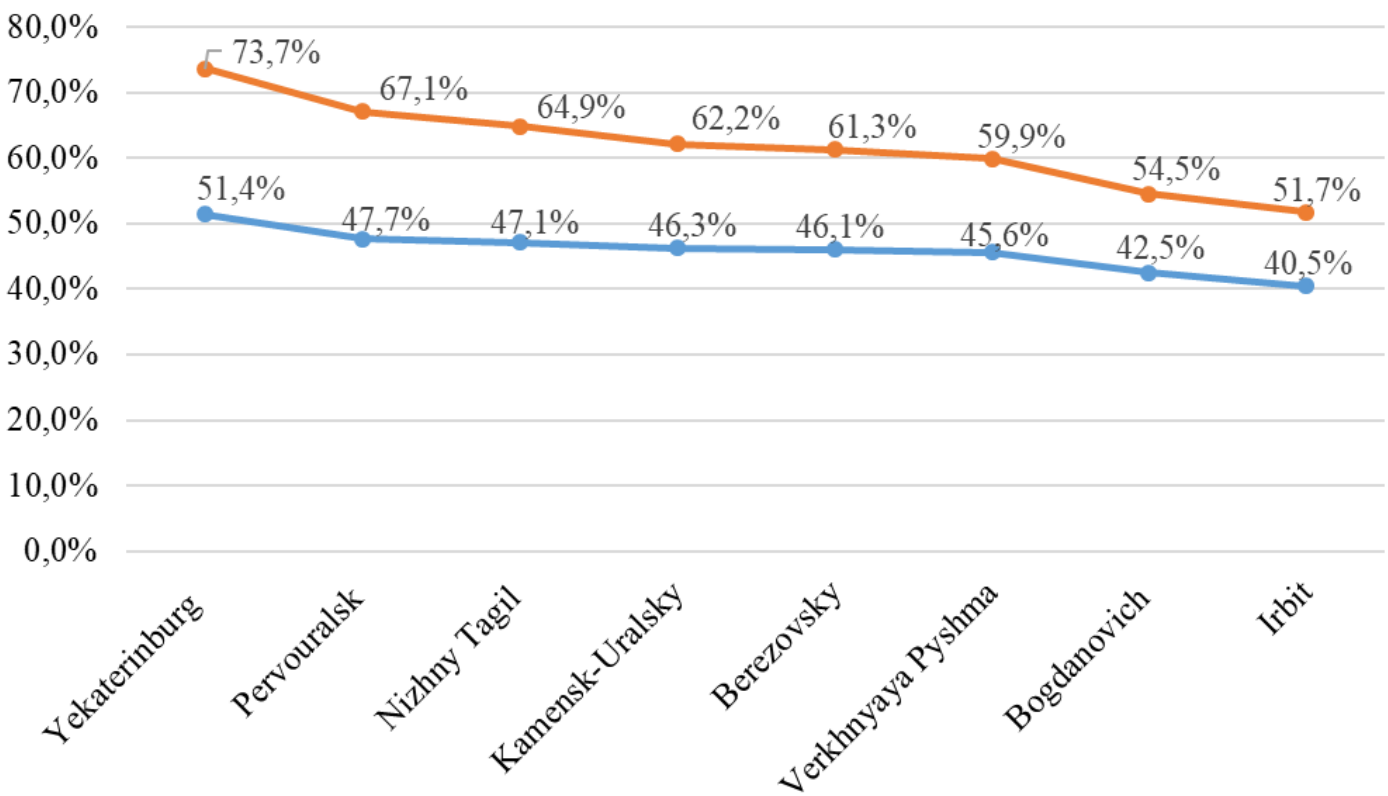

$\multimap$ Financial literacy level, $\% \multimap-$ Number of active users of digital financial services, $\%$

Figure 7. Comparison of trends in the activity of DFS users and the financial literacy level of population of the Sverdlovsk region, $\%$

One of the most valuable results was a comparative analysis of the activity of people using digital financial services and assessments of the level of financial literacy: the correlation is direct - the more actively the population uses DFS, the more financially competent it is (Figure 7). It cannot be said that the confirmation of this hypothesis is completely unexpected for the authors, but such convincing results expand the possibilities of increasing the financial knowledge level through the practice of using a wide range of financial services and technologies, that the task of increasing the level of financial literacy seems to be attainable. 
[3] The official website of the Federal Service for Civil Service of the Russian Federation, Electronic resource, Reference date: 02.27.2020: https://gks.ru [4] The official website of the Central Bank of the Russian Federation, Electronic resource.

https://www.cbr.ru/Ankets/MailForm.aspx?PartID=fing ram. Reference date: 10/10/2019

[5] Razumovskaya E.A. Personal Financial Planning: Theory and Process Modeling, Deutschland,

Saarbrucken: Palmarium Academic Publishing, 2016. $313 \mathrm{p}$.

[6] Razumovskaya E.A., Razumovskiy D.Yu. Approaches to Assessing the Optimality of Structure of Household Financial Resources and Financial Literacy of the Population, Finances, No. 1, 2020. - pp. 57 - 64. [7] Thaler R. New Behavioral Economics: Why Do People Violate the Rules of the Traditional Economy. M.: Publishing house ' $Э$ ', 2017, 368 p.

[8] Brounen D., Koedijk, K.G., Rachel A.J.

Household financial planning and savings behavior. Journal of International Money and Finance № 69, 2016, Pp. 95 - 107.

DOI:10.1016/j.jimonfin.2016.06.011

[9] Burke, M., Fry, J. How easy is it to understand consumer finance?, Economics Letters, № 177, 2019, Pp. 1 - 4. DOI:10.1016/j.econlet.2019.01.004 [10] Cardaci A. Inequality, household debt and financial instability: An agent-based perspective, Journal of Economic Behavior \& Organization, № 149, 2018, Pp. 434 - 458. DOI:10.1016/j.jebo.2018.01.010

[11] French D., Vigne S. The causes and consequences of household financial strain: a systematic review. International Review of Financial Analysis. - Volume 62, March 2019, Pp. 150 - 156 p. Access: https://doi.org/10.1016/j.irfa.2018.09.008.

[12] Ozili P.K. Impact of digital finance on financial inclusion and stability, Borsa Istanbul Review, № 18 (4), 2018, Pp. 329 - 340.

[13] Razumovskaia, E., Isakova, N., Razumovskyi, D., Mokeyeva, N., Kuklina, E. (2016) Financial Decisionmaking by the Population: Process Modeling and Trends, Indian Journal of Science and Technology, 9 (46). DOI: $10.17485 / \mathrm{ijst} / 2016 / \mathrm{v} 9 \mathrm{i} 46 / 107570$ 